\title{
Ethnobotany of edible plants in Muang District, Kalasin Province, Thailand
}

\author{
NATTHAKIT PHATLAMPHU ${ }^{1}$, SURAPON SAENSOUK ${ }^{1, \boldsymbol{v}}$, PIYAPORN SAENSOUK ${ }^{2}$, \\ AUEMPORN JUNSONGDUANG ${ }^{3}$ \\ ${ }^{1}$ Program of Biodiversity, Walai Rukhavej Botanical Research Institute, Mahasarakham University. Kham Riang, Kantharawichai, Maha Sarakham, \\ 44150, Thailand. "email:surapon.s@msu.ac.th \\ ${ }^{2}$ Department of Biology, Faculty of Sciences, Mahasarakham University. Kham Riang, Kantharawichai, Maha Sarakham, 44150, Thailand \\ ${ }^{3}$ Program of Biology, Department Science and Technology, Faculty of Liberal of Art and Science, Roi Et Rajabhat University. Ko Kaeo, Selephum, Roi \\ Et 45120, Thailand
}

Manuscript received: 7 October 2021. Revision accepted: 23 November 2021.

\begin{abstract}
Phatlamphu N, Saensouk S, Saensouk P, Jungsongduang A. 2021. Ethnobotany of edible plants in Muang District, Kalasin Province, Thailand. Biodiversitas 22: 5432-5444. Edible plants have been used as a food source and have had other purposes since ancient times, but urbanization and modernization might be obscuring traditional knowledge. Therefore, this research aimed to conduct a study on the ethnobotany of indigenous people in Muang District, Kalasin Province based on edible plants by focusing on their specific uses. Data was collected through semi-structured interviews and focus group discussions from March 2019 to February 2021. Quantitative analysis was applied using the Cultural Important Index (CI), Fidelity Level (FL) and Informant Consensus Factor (ICF). Cluster analysis based on the Jaccard's Similarity Index (JI) was calculated for the similarity of edible plant uses in four communities is as follows: urban/semi-urban (UB), forest community (FC), wetland community (WC) and community in valley (CV). There were 140 edible plant species that belonged to 125 genera and 62 families. The most important edible plants species were Tamarindus indica which had a CI of 2.65 followed by Bambusa bambos (2.00) and Citrus hystrix (1.90). The highest FL value is given for 51 edible plant species with $100 \%$ FL. The ICF is a range of 0 to 1 ; the most consensus of ailment categories was the treatment of wound (ICF $=1.00$ ). The JI varied between 0.2640 and 0.2971 ; the highest JI was the pairs of WC and FC. UPGMA cluster analysis indicated that UB is isolated as they have less similarity to other communities. The results show a risk of traditional knowledge loss due to the expansion of the economic system at all levels and the advancement of modern medicine.
\end{abstract}

Keywords: Edible plants, ethnobotany, Isan region, Kalasin Province, Similarity Index

Abbreviations: CI: Cultural Important Index, FL: Fidelity Level, ICF: Informant Consensus Factor, JI: Jaccard's Similarity Index

\section{INTRODUCTION}

Plants are a special kingdom of organisms as they can produce their own energy through the main elements and sunlight, and they offer benefits to other kingdoms of life. Humans have used plants as food, drugs and to meet other needs since ancient times (Fernando 2012; Katiyar et al. 2021; Saensouk and Saensouk 2021). However, the species diversity of plants gives a variety of plant uses depending on their form and culture in each region around the world. Therefore, edible plants have other essential uses in addition to food for people (Saensouk et al. 2016; Saisor et al. 2021).

Thailand is a country in Southeast Asia, which is located in the tropical zone and comprised of several distinct geographic regions; this has resulted in rich biodiversity in Thailand. From past to present, Thai people have used natural products. Several things had been made from the wild ingredients that are fundamental factors in human life (foods and medicines) and as tools to solve basic problems, such as the creation of artifacts or houses that are built from different hardwood plant species, and these help people seek a better livelihood. This is reflected by Thailand having been historically a country with extensive knowledge of traditional plant uses (Robinson 2007).

The Northeast of Thailand or "Isan Region" is the largest and most populous region in Thailand $\left(25,000 \mathrm{~km}^{2}\right)$, and is located on the part of the Khorat Plateau $\left(14-19^{\circ} \mathrm{N}\right.$, $\left.101-106^{\circ} \mathrm{E}\right)(\mathrm{Ch}$ eonkwan et al. 2021). There are 11 main ethnic groups of indigenous people in the Isan region, and the biggest group is the Thai Isan (Thai Lao) which is characterized by the settlement of two ethnic groups between Thai and Lao people (United Nations 2011). This is a reason for the knowledge sharing by local people on the properties of food and traditionally used plants. For over four decades, rice farming has become the main commercial crop of the Isan Region (Cramb 2020). The Isan region has undergone a major change in the structure of land uses due to socio-economic drivers and the large industry in agriculture (Grünbühel 2003). There is an area cultivated to grow cash crops that provides a major source of agricultural raw materials (such as sugarcane, cassava, rubber, rice, etc.) as inputs for nearby factories. This has a huge effect on land-use change to that of the indigenous people. 
Kalasin is one of 20 provinces in the Isan Region that faces a problem about traditional knowledge loss caused by land-use change and the expansion of the economy and utility system, which is in accordance with other ethnobotanical studies in Thailand and other countries (Kayani et al. 2015; Khuankaew et al. 2014; Reyes-García et al. 2013; Srithi et al. 2009). Some parts of forest areas have been turned into cultivation areas and housing, which might be the cause of the loss of diversity in edible plant species.

Therefore, the ethnobotany of edible plants in Muang District, Kalasin Province, was surveyed to study the plant species diversity and their uses with a focus on local cultural values, and then this information was applied to sustain the use of the resources and for nature conservation. In addition, more benefits for the people could be developed their own traditional knowledge.

\section{MATERIALS AND METHODS}

\section{Study area}

Kalasin Province is located in the center of northeastern Thailand (16²5'56.5"N 10330'28.3"E) (Figure 1). Kalasin is covered by a hilly landscape with dispersed ponds and swamps. The total area is 6,936 square kilometers. Normally, the weather is hot in the summer and quite cold in the winter. Muang District has an area of around 691.524 square kilometers. The area consists of valleys and plains with an altitude of around 140-250 meters above sea level.
There are mixed social patterns between urban and rural populations with 146,194 people in 17 sub-districts. Most of the population works in agriculture-related jobs (Kalasin Provincial Office SIPD 2013).

\section{Data collection}

The ethnobotany of edible plants in Muang District, Kalasin Province was collected between March 2019 and February 2021. The uses of edible plants were collected by the semi-structured interview method through randomly selected key participants (Numpulsuksant et al. 2021; Saisor et al. 2021; Susandarini et al. 2021) and focus group discussions with 40 informants from 17 sub-districts by random selection of 2-5 people per sub-district. In addition, to the local name and questionnaire about the parts of the edible plants used and consumption methods, their properties when the plants are used to cure diseases and heal patients were collected.

\section{Specimen collection and identification}

Plant specimens were collected from fields. Voucher specimens were deposited at the Mahasarakham University Herbarium. Plants specimens were identified to their scientific name based on the information from previous studies in Kalasin and other regions in Northeastern Thailand, using the available literature on plant diversity or the Flora of Thailand book, and verified using an online database, Plants of the World Online or POWO (Kew Science 2021).

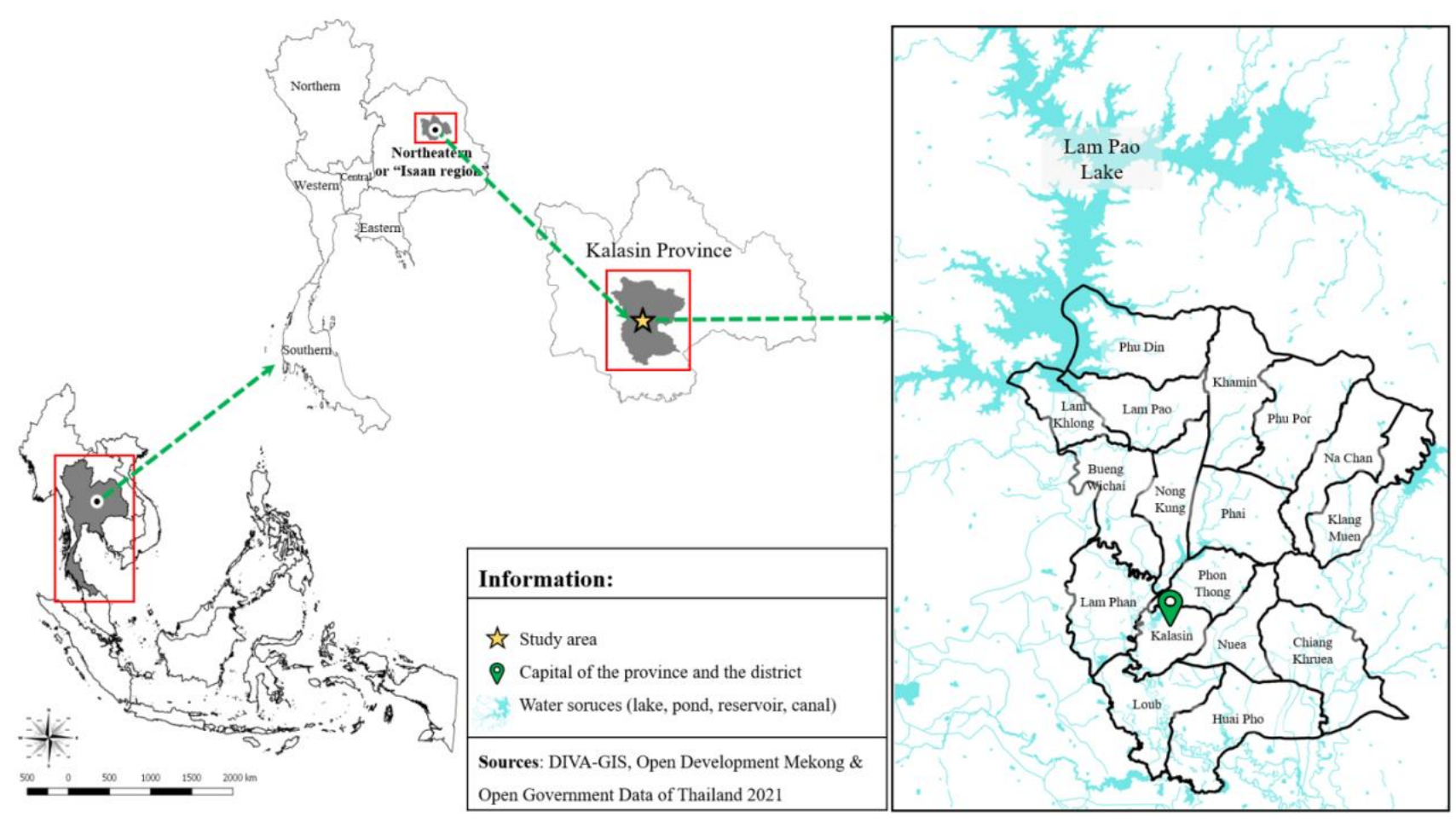

Figure 1. Sub-district level map of Muang district, Kalasin Province, Thailand (Kalasin Provincial Office SIPD 2013) 


\section{Quantitative analysis}

The analysis of the quantitative data was performed using the ethnobotanical index to calculate the Cultural Importance Index (CI) (Sutjaritjai et al. 2019) and Jaccard's Similarity Index (JI) (Silalahi and Nisyawati 2018)

\section{Cultural importance index; CI}

The Cultural Importance Index (CI) was used to demonstrate how important the edible plant was for people based on the data from the questionnaire and interviews about species that were used in daily lives (Tardío et al. 2008) and formulated as follows:

$$
\mathrm{CI}=\sum_{(\mathrm{u}=1)^{N C}} \sum_{(\mathrm{i}=1)^{N}} U R_{U i} / N
$$

Where $N C$ is the total number of use categories, $U R$ is the total number of use reports and $N$ is the total number of informants. Therefore, the CI index is the sum of the proportion of informants that mention each of the edible plant species for their use categories.

\section{Fidelity level; FL}

Fidelity level is used to analyze the most interesting plant species that were used to cure disease in each ailment category (Friedmann et al. 1986; Numpulsuksant et al. 2021).

$$
\% \mathrm{FL}=(N p / N) \times 100
$$

When $N p$ is the number of used reports of that plant species in that ailment, and $N$ is the total number of plant species in that ailment.

\section{Informant consensus factor; ICF}

The Informant consensus factor is used to test an agreement of informants (Trotter and Logan 1986). The higher ICF (near 1) means that informants use the plant to treat the same ailments (Heinrich et al. 1998).

$$
\mathrm{IAR}=(N u r-N t) /(N u r-1)
$$

When Nur is the used-report of the specific use of the plant in each ailment, and $N t$ is the total number of plant species used in each ailments

\section{Jaccard's Similarity Index; JI}

Jaccard's Similarity Index (JI) were calculated to compare the edible plant utilization in four areas that were dominated by their unique geographic patterns when the local people in Muang District live near natural resources or in areas that are economic zones, as follows: urban/semiurban (UB), forest community (FC), wetland community (WC) and community in valley (CV). This will help to focus on differences in plant utilization between the four community areas located in different ecosystems and species similarities among the communities were analyzed with UPGMA cluster analysis (Hammer et al. 2001). The formulae are as follows:

$$
\mathrm{JSC}=c /(a+b+c)
$$

When $a$ is the number of edible plant species used in area $\mathrm{A}, b$ is in area $\mathrm{B}$ and $c$ is the number of edible plant species used in both areas A and B (Jaccard 1902).

\section{RESULTS AND DISCUSSION}

\section{Number of species uses and edible plant families}

We found 140 edible plant species belonging to 125 genera and 62 families. The Fabaceae had the highest number (14 species) of edible plant species followed by Lamiaceae and Zingiberaceae (seven species in each family) and Apiaceae (six species) (Table 1). This was in accordance with Thongpukdee et al. (2014) who stated that Fabaceae had the highest number of species members utilized as vegetables in Huai Mek District, Kalasin Province. Punchay et al. (2020) stated that Fabaceae and Zingiberaceae had the highest number of edible plants used by two ethnic groups of local people (Thai Karen and Lawa) from northern Thailand. In a previous study, CruzGarcia et al. (2016) indicated that Fabaceae was the most common family found in rice field ecosystems in Kalasin Province. This confirms other ethnobotany research projects (Junsongduang et al. 2013; Ong and Kim 2017; Pholhiamhan et al. 2017). Fabaceae is of great ethnobotanical importance in indigenous and urban communities throughout the world, and this family is one of the largest plant families in the world, including 751 genera and 19,500 species (Christenhusz and Byng 2016; Molares and Ladio 2011). This family has been widely used for food consumption and a variety of other purposes by people. In this study, Fabaceae was used as food by indigenous and urban communities, and some species are used by folk healers for the treatment of different diseases (Rahman and Parvin 2014). This was in accordance with other research projects on Fabaceae state that legume species are more intimated to the indigenous people and important to the health of people around the world (Gwalwanshi et al. 2014; Oladeji et al. 2021; Sutjaritjai et al. 2019). While, thirty-two plant families gave the lowest number of edible plant species (one species each) and they were used by a smaller number of people.

The sub-district with the highest number of edible plant species was Klang Muen (107 species) followed by Phu Por and Lam Khlong giving 98 and 96 species, respectively. Most of the edible plants found in Klang Muen and Lam Klong are not used for food, but rather by the folk healers who still keep and transfer the traditional medicine knowledge to their descendants in those two subdistricts in Muang District, Kalasin Province. Most of the edible plant species found in Phu Por were used for food. $\mathrm{Phu}$ Por is a sub-district located in the crop-valley ecosystem which is distant from the local market, and the main occupation of the people in Phu Por is agricultural. They plant a lot of home gardens for food supply adapted to the season and environment aspects. Whereas, Loup subdistrict has the lowest number (61 species). However, the number of edible plant species found in Loup was not different from five other sub-districts, such as Nuea (63 species), Phai (64 species) and Phu Din, Nong Kung and 
Khamin (65 species) (Figure 2). In addition, 51 species of edible plant were used in all sub-districts and 35 species were used in only a single sub-district (Figure 3). Therefore, from the results shown in Figure 2 and Figure 3 it can be concluded that there are unnoticed able differences in the number of edible plants used when compared to the number of edible species based on the subdistrict administrative/municipality area.

Table 1. Twelve most common plant families are used by local people in Muang District, Kalasin Province, Thailand

\section{Family} Number of species

Fabaceae

Lamiaceae, Zingiberaceae

Apiaceae

Solanaceae

Amaryllidaceae, Apocynaceae, Asteraceae, Cucurbitaceae, Euphorbiaceae, Moraceae, Poaceae

Acanthaceae, Anacardiaceae, Annonaceae, Malvaceae, Myrtaceae, Rhamnaceae, Rutaceae

Arecaceae, Bignoniaceae, Brassicaceae, Meliaceae, Menispermaceae, Phyllanthaceae, Piperaceae, Smilacaceae

Alismataceae, Amaramthaceae, Araceae, Basellaceae, Caricaceae, Celastraceae, Cleomaceae, Clusiaceae,

Colchicaceae, Connaraceae, Convulvulaceae, Costaceae, Dracaenaceae, Fagaceae, Hypericaceae, Irvingiaceae,

Lauraceae, Lecythidaceae, Loganiaceae, Lythraceae, Melastomaceae, Muntingiaceae, Musaceae, Nelumbonaceae,

Nymphaeaceae, Opiliaceae, Oxalidaceae, Plantaginaceae, Polygonaceae, Sapindaceae, Sapotaceae,

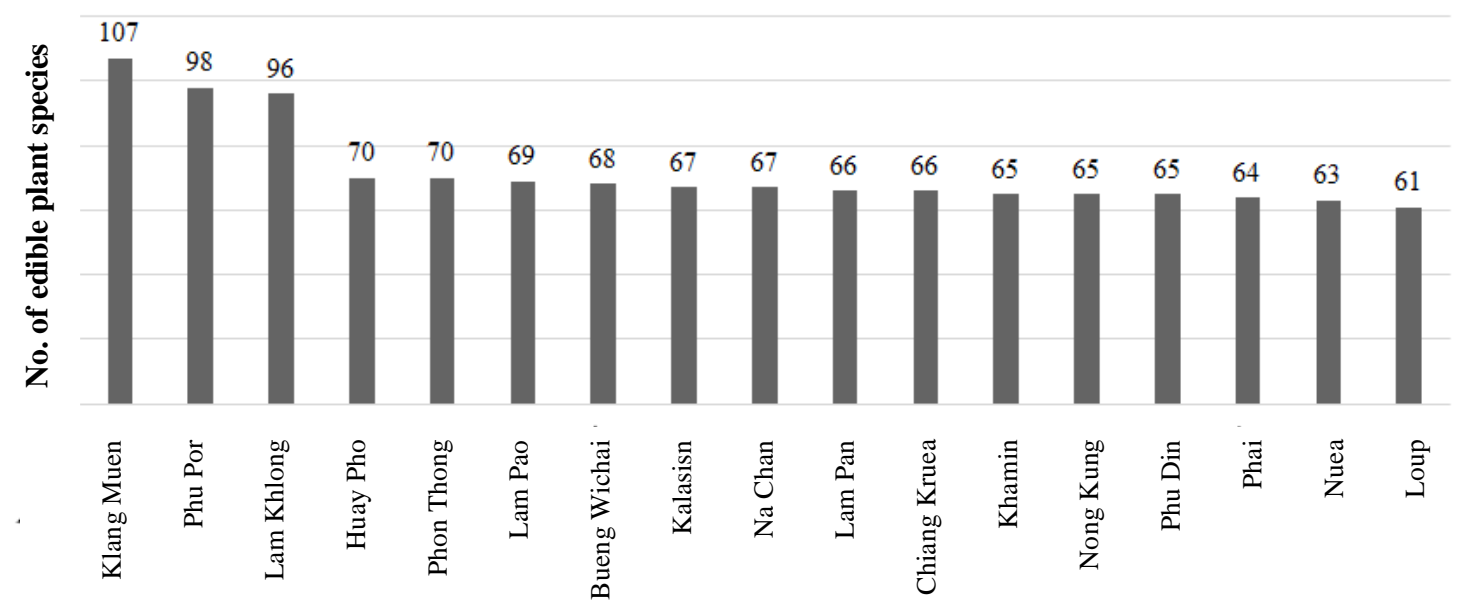

Sub-districts

Figure 2. Number of edible plants used by local people in 17 sub-districts in Muang District, Kalasin Province, Thailand

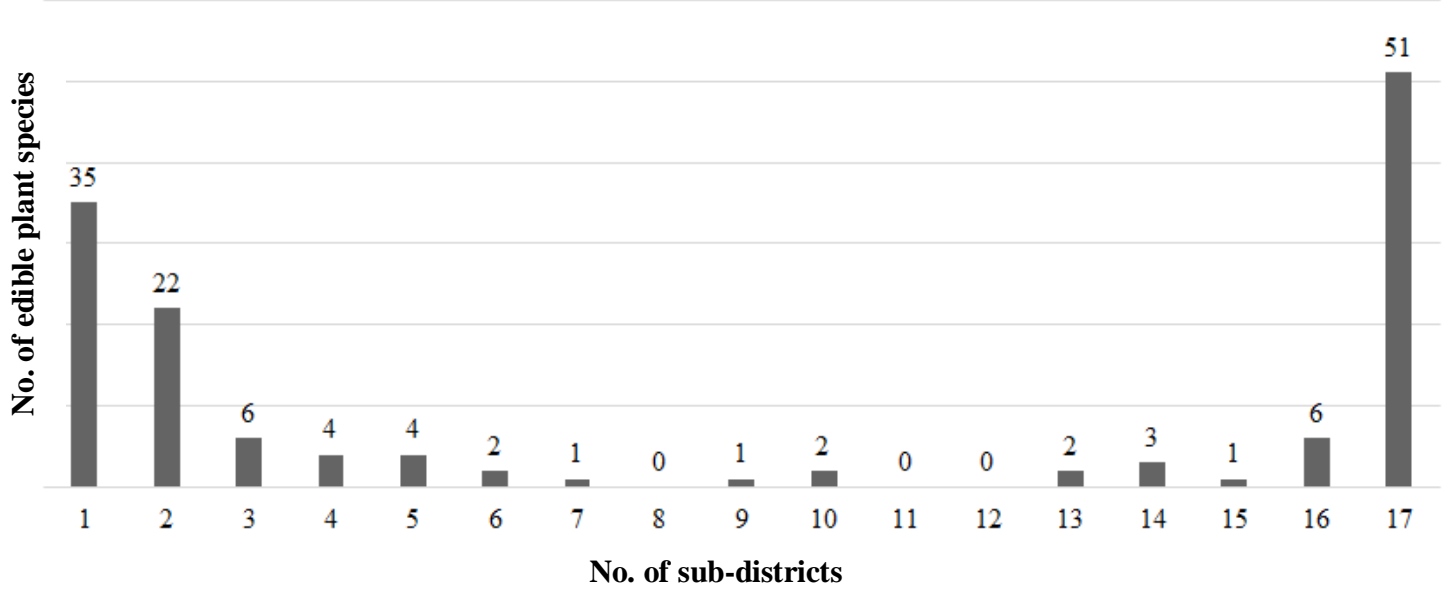

Figure 3. Frequency of occurrence of edible plants species in 17 sub-districts in Muang District, Kalasin Province, Thailand 


\section{Cultural important index (CI)}

The edible plants that were used in several categories and mentioned by a high number of informants tended to have high CI values. On the other hand, the edible plant species with the lowest CI values were used by a few people. Tamarindus indica had the highest CI (2.65) followed by Bambusa bambos (2.00) and Citrus hystrix (1.90). Tamarindus indica is the edible plant used as a fruit, and their young leaves can be used in cooking to give a sour flavor by transforming into a tamarind pulp. Moreover, T. indica can be used for other purposes. Their fruit can be used as a laxative; the heartwood is used as a traditional way to care for women after giving birth. Tamarin's stem can be used to make furniture, tools and for building a residence. In addition, tamarind is used in local beliefs, including worship or ceremonies in the Isan traditional culture. Several people grow tamarind trees at the front of their house, as they believe that tamarind would help the inhabitant get respect from other people. While $B$. bambos was used for its shoots for foods and its stem can be used for several purposes. According to an ethnobotany study of bamboo used in the Sangirese (North Celebes), bamboo can be used as a construction material, handicraft, furniture and food (Liana et al. 2017). Citrus hystrix has its fruit and leaves used by cooks to make food fragrant and appetizing. In traditional medicine, $C$. hystrix is used as an ingredient in a traditional formula to make Thai herbal compress balls (Wongpanit et al. 2018) which are steamed before being applied to the human body in traditional Thai massages. Moreover, C. hystrix is also used to prevent malodor, which is caused by bacteria (Khuntayaporn and Suksiriworapong 2017). The lowest CI (0.03) was found for 20 species of edible plants that were used in traditional ways to cure sicknesses which are known by only a few informants who are elder folk healers (Table 2). Therefore, this is a key conclusion about the conservation of local wisdom when the knowledge is only kept by a few people and there is a risk of knowledge loss due to the development of public health systems where people can access good quality primary health care and antibiotics. Similarly, with the ethnobotany of traditional medicinal plants studied the Dayak Desa community in Sintang (West Kalimantan, Indonesia) and the traditional study of medicinal plants in Kampung Masjid Ijok (Perak, Malaysia), the traditional knowledge of the medicinal plants was only known by the older generation and there is a risk of knowledge loss due to modern medicine and a change in health care culture (Supiandi et al. 2019; Ramli et al. 2021).

\section{Fidelity level (FL) and Informant consensus factor (ICF)}

Two folk healers and their patients have used 68 edible plants as their traditional medicinal remedies $(48.22 \%$ of total edible species found in a study area) to cure diseases and any symptoms separated for 15 major ailment categories based on National List of Essential Medicines (Natural Drug Information 2013) (Table 3). Fifty-one species were given $100 \%$ of FL when they were used in a single category; for example, Curcuma comosa are applied to rejuvenate a woman as the traditional postpartum healing (Noomhorm et al. 2014), Thumbergia laurifolia is used to neutralize in some venomous insects (Vongthip et al. 2021), etc. Meanwhile, the ICF varied between 0.00-1.00; the highest value was giving a high degree of consensus for injuries when Chromolaena odorata was used to stop bleeding after small accidents (Pandith et al. 2013). However, the lower FL means that a plant species is being used for many ailments and the lowest ICF was recorded for seven categories $(\mathrm{ICF}=0)$ when the number of plant use-record was equal to the number of plant species, these results shown that the variety of plant uses in each lowest categories and their properties are known by a few numbers of informants, nor people have less knowledge about traditional medicine (Inta et al. 2013).

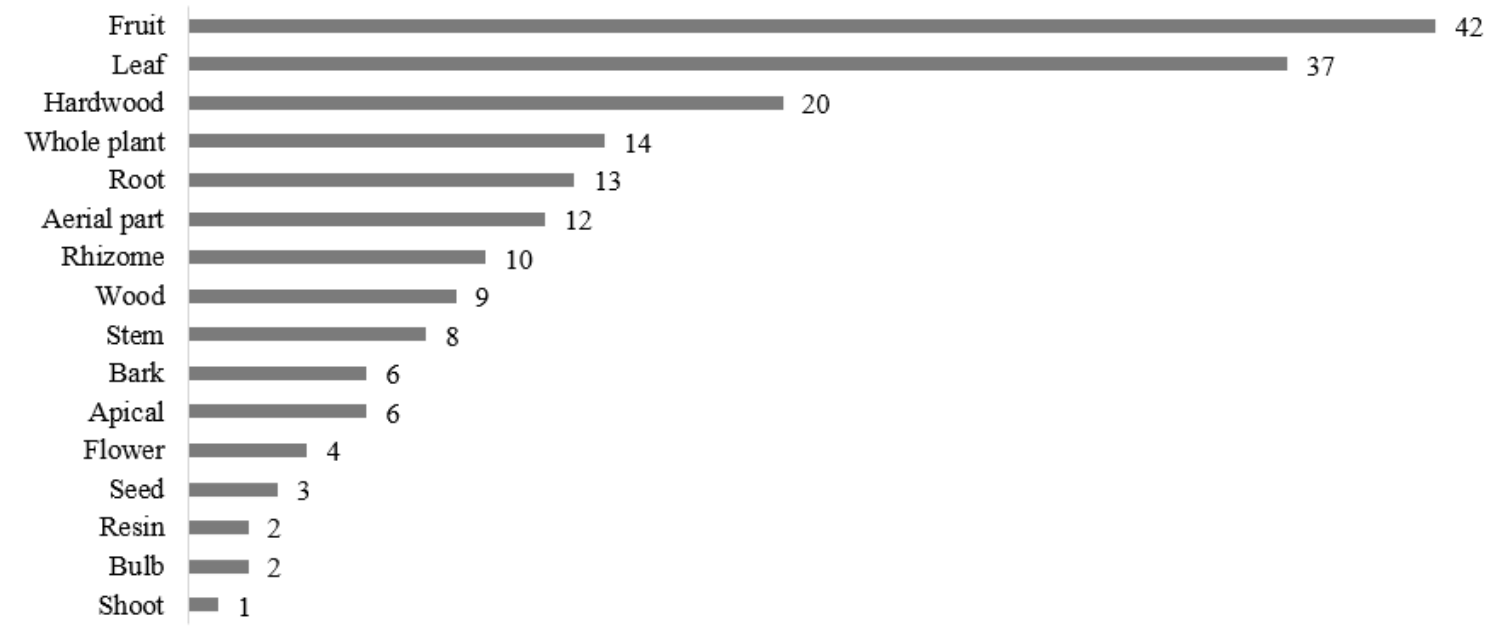

Figure 4. Edible plant parts used in Muang District, Kalasin Province, Thailand 
Table 2. Family and scientific names of edible plant species used in Maung District, Kalasin Province, Thailand

\begin{tabular}{|c|c|c|c|c|c|c|c|}
\hline Family & Scientific name & Local name & $\begin{array}{l}* \text { Use } \\
\text { categories }\end{array}$ & FL $(\%)$ & Instruction & CI & Collector no. \\
\hline Acanthaceae & Andrographis paniculata & Fa thalai chon & $\mathrm{Me}$ & 100 & Boil whole plant to cough relief. & 0.25 & Phatlamphu097 \\
\hline Acanthaceae & Barleria lupulina & Salet phang phon & $\mathrm{Me}$ & 100 & Pound leaf and mix with alcohol to cure the skin disease. & 0.18 & Phatlamphu098 \\
\hline Acanthaceae & Thunbergia laurifolia & Rang chuet & $\mathrm{Me}$ & 100 & Pound leaf with water and masking to treat the venomous. & 0.10 & Phatlamphu099 \\
\hline Alismataceae & Limnocharis flava & Phak pai & Fo & - & Eaten fresh as vegetable. & 0.98 & Phatlamphu139 \\
\hline Amaranthaceae & Achyranthes aspera & Phan ngu & $\mathrm{Me}$ & 100 & Boil and drink for diuresis. & 0.03 & Phatlamphu129 \\
\hline Amaryllidaceae & Allium ascalonicum & Homdaeng & Fo & - & Used as food ingredients. & 1.00 & Phatlamphu028 \\
\hline Amaryllidaceae & Allium fistulosum & Hombua & Fo & - & Eaten as vegetable or used as food ingredients. & 1.00 & Phatlamphu029 \\
\hline Amaryllidaceae & Allium sativum & Kra thiam & Fo, Me & 100 & $\begin{array}{l}\text { Eaten as vegetable or used as food ingredients, Boil the dry false stem } \\
\text { and dry leaf mix with water and bath to treat the skin disease. }\end{array}$ & 1.08 & Phatlamphu031 \\
\hline Amaryllidaceae & Allium tuberosum & Kui chai & Fo & - & Eaten as vegetable or used as food ingredient. & 0.15 & Phatlamphu030 \\
\hline Anacardiaceae & Gluta usitata & Rak yai & $\mathrm{Me}$ & 100 & Boil bark and drink to cure stomachache. & 0.10 & Phatlamphu091 \\
\hline Anacardiaceae & Mangifera indica & Mak muang & Fo & - & Eaten as fruit. & 1.00 & Phatlamphu135 \\
\hline Anacardiaceae & Spondias pinnata & Mak kok & Fo & - & Used as food flavoring. & 0.65 & Phatlamphu049 \\
\hline Annonaceae & Annona squamosa & Makkhieb & Fo, $\mathrm{Me}$ & 100 & Eaten as fruit, rubbing dry fruit mix with water to cure abscess. & 0.13 & Phatlamphu138 \\
\hline Annonaceae & Polyalthia debilis & Kluai tao & $\mathrm{Me}$ & 100 & Boil whole plant and drink to cure diarrhea. & 0.03 & Phatlamphu114 \\
\hline Annonaceae & Polyalthia evecta & Nom noi & $\mathrm{Me}$ & 100 & Boil root and drink abdominal distention. & 0.05 & Phatlamphu115 \\
\hline Apiaceae & Anethum graveolens & Thian khao plueak & Fo & - & Eaten as vegetable or used as food ingredient. & 1.00 & Phatlamphu017 \\
\hline Apiaceae & Apium graveolens & Khuen-chai & Fo & - & Eaten as vegetable or used as food ingredient. & 0.35 & Phatlamphu018 \\
\hline Apiaceae & Centella asiatica & Bua bok & Fo & - & Eaten as vegetable. & 0.38 & Phatlamphu004 \\
\hline Apiaceae & Coriandrum sativum & Phak chi & Fo & - & Eaten as vegetable or used as food ingredient. & 0.98 & Phatlamphu015 \\
\hline Apiaceae & Eryngium foetidum & Hom phe & Fo & - & Eaten as vegetable or used as food ingredient. & 1.00 & Phatlamphu016 \\
\hline Apiaceae & Oenanthe javanica & Phak chi lom & Fo & - & Eaten as vegetable. & 0.93 & Phatlamphu019 \\
\hline Apocynaceae & Carissa carandas & Nam daeng & Fo & - & Eaten as fruit. & 0.15 & Phatlamphu133 \\
\hline Apocynaceae & Cryptolepis buchananii & Thao en on & $\mathrm{Me}$ & $\begin{array}{l}50 \\
50\end{array}$ & $\begin{array}{l}\text { Boil hardwood and drink to cough relief } \\
\text { Boil leaf mix with water and bath to rejuvenate as the traditional } \\
\text { postpartum healing }\end{array}$ & 0.08 & Phatlamphu116 \\
\hline Apocynaceae & Myriopteron extensum & Cha em & Fo & - & Eaten as vegetable or used as food ingredient. & 0.13 & Phatlamphu076 \\
\hline Apocynaceae & Streptocaulon juventas & Khreau prasong & $\mathrm{Me}$ & 100 & Boil root and drink to cure stomachache. & 0.03 & Phatlamphu117 \\
\hline Araceae & Amorphophallus brevispathus & Elok & Fo & - & Used as food ingredients. & 0.50 & Phatlamphu136 \\
\hline Arecaceae & Calamus viminalis & Wai khom & Fo, Eq & - & Used as food ingredients, used the stem as the equipment. & 1.10 & Phatlamphu137 \\
\hline Arecaceae & Cocos nucifera & Mak phrao & Fo & - & Eaten as fruit. & 1.00 & Phatlamphu005 \\
\hline Asteraceae & Artemisia lactiflora & Ching-chu-chai & Fo & - & Eaten as vegetable or used as food ingredient. & 0.05 & Phatlamphu075 \\
\hline Asteraceae & Blumea balsamifera & Nat yai & $\mathrm{Me}$ & 100 & Bring leaf lie by the fire as the traditional postpartum healing. & 0.25 & Phatlamphu120 \\
\hline Asteraceae & Chromolaena odorata & Sap suea & $\mathrm{Me}$ & $\begin{array}{l}25 \\
75\end{array}$ & $\begin{array}{l}\text { Boil fresh root and drink to cure stomachache. } \\
\text { Pound leaf and masking wound to stop bleeding. }\end{array}$ & 0.03 & Phatlamphu121 \\
\hline Asteraceae & Pluchea indica & Khlu & $\mathrm{Me}$ & 100 & Squash leaf mix with water to cure hemorrhoid. & 0.03 & Phatlamphu118 \\
\hline Athyriaceae & Diplazium esculentum & Phak kut khao & Fo & - & Eaten as vegetable. & 0.15 & Phatlamphu079 \\
\hline Basellaceae & Basella alba & Phak plang & Fo & - & Eaten as vegetable. & 0.18 & Phatlamphu080 \\
\hline Bignoniaceae & Dolichandrone serrulata & Khae $\mathrm{Na}$ & Fo & - & Eaten as vegetable. & 0.35 & Phatlamphu078 \\
\hline Bignoniaceae & Oroxylum indicum & Lin fah & Fo & - & Used as food ingredients. & 0.88 & Phatlamphu026 \\
\hline
\end{tabular}




\begin{tabular}{|c|c|c|c|c|c|c|c|}
\hline Brassicaceae & Brassica oleracea & Phak kha na & Fo & - & Eaten as vegetable, used as food ingredient. & 0.93 & Phatlamphu020 \\
\hline Brassicaceae & Rorippa indica & Phak lin pee & Fo & - & Eaten as vegetable. & 0.05 & Phatlamphu048 \\
\hline Caricaceae & Carica papaya & Makhoong & Fo, Me & 100 & $\begin{array}{l}\text { Eaten as vegetable, used as food ingredient, used their resin to cure skin } \\
\text { disease. }\end{array}$ & 1.03 & Phatlamphu054 \\
\hline Celastraceae & Salacia chinensis & $\begin{array}{l}\text { Kamphaeng Chet } \\
\text { Chan }\end{array}$ & $\mathrm{Me}$ & 100 & Used stem as the crude drug ingredient to cure hemorrhoid. & 0.05 & Phatlamphu123 \\
\hline Cleomaceae & Cleome gynandra & Phak sian & Fo & - & Eaten as vegetable or used as food ingredient. & 0.85 & Phatlamphu067 \\
\hline Clusiaceae & Garcinia cowa & Maksommong & Fo & - & Eaten as vegetable. & 0.03 & Phatlamphu074 \\
\hline Colchicaceae & Gloriosa superba & Dong dueng & $\mathrm{Me}$ & 100 & Used whole plant as the crude drug ingredient to cure mumps (parotitis). & 0.03 & Phatlamphu119 \\
\hline Connaraceae & Ellipanthus tomentosus & Kham rok & $\mathrm{Me}$ & 100 & Boil hardwood and drink to cure stomachache. & 0.05 & Phatlamphu132 \\
\hline Convulvulaceae & Ipomoea aquatica & Phak bung & Fo & - & Eaten as vegetable, used as food ingredient. & 1.00 & Phatlamphu046 \\
\hline Costaceae & Cheilocostus speciosus & Ueang mai na & $\mathrm{Me}$ & 100 & Boil hardwood and drink to cure dysuria & 0.03 & Phatlamphu111 \\
\hline Cucurbitaceae & Coccinia grandis & Phak tam lueng & Fo & - & Eaten as vegetable, used as food ingredient. & 1.00 & Phatlamphu047 \\
\hline Cucurbitaceae & Cucurbita moschata & Makuae & Fo & - & Used as food ingredient. & 1.00 & Phatlamphu072 \\
\hline Cucurbitaceae & Momordica charantia & Ma ra khi nok & Fo & - & Eaten as vegetable, used as food ingredient. & 0.23 & Phatlamphu021 \\
\hline Cucurbitaceae & Trichosanthes cucumerina & Buap & Fo & - & Used as food ingredient. & 0.03 & Phatlamphu073 \\
\hline Dracaenaceae & Dracaena cochinchinensis & Chan Daeng & $\mathrm{Me}$ & 100 & Used hardwood as the crude drug ingredient to cure influenza. & 0.03 & Phatlamphu094 \\
\hline Euphorbiaceae & Cladogynos orientalis & Chetta phang khi & $\mathrm{Me}$ & 100 & Boil hardwood and drink to cure stomachache. & 0.03 & Phatlamphu095 \\
\hline Euphorbiaceae & Croton persimilis & Plao yai & $\mathrm{Me}$ & 100 & Bring leaf lie by the fire as the traditional postpartum healing. & 0.08 & Phatlamphu092 \\
\hline Euphorbiaceae & Euphorbia hirta & Nam nom ratchasi & $\mathrm{Me}$ & 100 & Boil hardwood and drink to cough relief. & 0.05 & Phatlamphu093 \\
\hline Euphorbiaceae & Suregada multiflora & Khan thong phayabat & $\mathrm{Me}$ & 100 & Used hardwood as the crude drug to cure kidney disease. & 0.03 & Phatlamphu096 \\
\hline Fabaceae & Acacia pennata & Phak kha & Fo & - & Used as food ingredient. & 1.00 & Phatlamphu052 \\
\hline Fabaceae & Acrocarpus fraxinifolius & Sadao chang & $\mathrm{Me}$ & 100 & Used hardwood as the crude drug to cure kidney disease. & 0.03 & Phatlamphu130 \\
\hline Fabaceae & Butea monosperma & Charn & $\mathrm{Me}$ & 100 & Used hardwood as the crude drug to cure kidney disease. & 0.03 & Phatlamphu023 \\
\hline Fabaceae & Caesalpinia sappan & Fang & Me, Dy & $\begin{array}{l}50 \\
50\end{array}$ & $\begin{array}{l}\text { Used hardwood as the crude drug ingredient to cure influenza. } \\
\text { Used stem as the crude drug ingredient to cure hemorrhoid. }\end{array}$ & 0.15 & Phatlamphu024 \\
\hline Fabaceae & Cassia fistula & Khun & $\mathrm{Me}, \mathrm{Cu}$ & 100 & $\begin{array}{l}\text { Bring hardwood lie by the fire as the traditional postpartum healing, } \\
\text { local people grown Khun at the front of their house and used their } \\
\text { flower in the auspicious ceremony. }\end{array}$ & 0.40 & Phatlamphu077 \\
\hline Fabaceae & Clitoria ternatea & Anchan & Me, Dy & 100 & Pound flower with water as shampoo. & 0.15 & Phatlamphu122 \\
\hline Fabaceae & Codariocalyx gyroides & Ton khao chi & $\mathrm{Me}$ & 100 & Used fruit as the crude drug ingredient as Leukemia treatment. & 0.05 & Phatlamphu131 \\
\hline Fabaceae & Leucaena leucocephala & Phak kased & Fo & - & Eaten as vegetable, used as food ingredient. & 1.00 & Phatlamphu053 \\
\hline Fabaceae & Neptunia prostrata & Phak krachet & Fo & - & Used as food ingredient. & 0.80 & Phatlamphu128 \\
\hline Fabaceae & Pithecellobium dulce & Mak kham thet & Fo & - & Eaten as fruit. & 1.00 & Phatlamphu071 \\
\hline Fabaceae & Senna alata & Chumhet thet & $\mathrm{Me}$ & 100 & Used leaf as the crude drug ingredient to cure ringworm. & 0.08 & Phatlamphu006 \\
\hline Fabaceae & Senna siamea & Khi lek & Fo, Me & 100 & Used as food ingredient, boil and drink as a laxative. & 1.53 & Phatlamphu025 \\
\hline Fabaceae & Sesbania gradiflora & Khae & Fo & - & Used as food ingredient. & 0.83 & Phatlamphu050 \\
\hline \multirow[t]{5}{*}{ Fabaceae } & Tamarindus indica & Mak kham & $\begin{array}{l}\mathrm{Fo}, \mathrm{Me} \\
\mathrm{Eq}, \mathrm{Cu}\end{array}$ & 67 & $\begin{array}{l}\text { Bring hardwood lie by the fire as the traditional postpartum healing, boil } \\
\text { and mix with water and bath to wound healing (medicine). }\end{array}$ & 2.65 & Phatlamphu022 \\
\hline & & & & 33 & $\begin{array}{l}\text { Eaten as fruit and as a laxative. Eaten as fruit, used as food ingredient } \\
\text { (food and medicine). }\end{array}$ & & \\
\hline & & & & & Used stem for building house or equipment, local people grown Mak & & \\
\hline & & & & & kham (tamarind) at the front of their house as they believe that Mak & & \\
\hline & & & & & $\begin{array}{l}\text { kham would help the inhabitant get respect from other people (local } \\
\text { belief). }\end{array}$ & & \\
\hline
\end{tabular}




\begin{tabular}{|c|c|c|c|c|c|c|c|}
\hline Fagaceae & Castanopsis piriformis & Kho hin & $\mathrm{Me}$ & 100 & $\begin{array}{l}\text { Bring root lie by the fire as the traditional postpartum healing, boil and } \\
\text { mix with water and bath to wound healing (medicine). }\end{array}$ & 0.15 & Phatlamphu110 \\
\hline Hypericaceae & Cratoxylum formosum & Phak Tio & Fo & - & Eaten as vegetable. & 0.93 & Phatlamphu043 \\
\hline Irvingiaceae & Irvingia malayana & Bok & Fo, Dy & - & Eaten as fruit, used bark as the dyer. & 0.20 & Phatlamphu032 \\
\hline Lamiaceae & Mentha $\times$ cordifolia & Phak serm & Fo & - & Eaten as vegetable, used as food ingredient. & 1.00 & Phatlamphu134 \\
\hline Lamiaceae & Oсітит $\times$ africanum & Maeng lak & Fo & - & Used as food ingredient. & 1.00 & Phatlamphu058 \\
\hline Lamiaceae & Ocimum basilicum & Horapha & Fo & - & Eaten as vegetable, used as food ingredient. & 1.00 & Phatlamphu059 \\
\hline Lamiaceae & Ocimum tenuiflorum & Ka phrao & Fo & - & Used as food ingredient. & 1.00 & Phatlamphu057 \\
\hline Lamiaceae & Orthosiphon aristatus & Phayab mek & $\mathrm{Me}$ & 100 & Used stem as the crude drug ingredient to muscle pains relief. & 0.03 & Phatlamphu103 \\
\hline Lamiaceae & Pogostemon cablin & Pim sen & $\mathrm{Me}$ & 100 & Used stem as the crude drug ingredient to muscle pains relief. & 0.03 & Phatlamphu104 \\
\hline Lamiaceae & Vitex pinnata & Tin nok & $\mathrm{Me}$ & $\begin{array}{l}50 \\
50\end{array}$ & $\begin{array}{l}\text { Boil hardwood and root and drink to cure stomachache. } \\
\text { Boil hardwood and root and drink to cure diabetes. }\end{array}$ & 0.03 & Phatlamphu105 \\
\hline Lauraceae & Cinnamoтит camphora & Karabun & $\mathrm{Me}$ & 100 & Used stem as the crude drug ingredient to muscle pains. & 0.05 & Phatlamphu106 \\
\hline Lecythidaceae & Careya arborea & Kradon & Fo & - & Eaten as vegetable. & 0.68 & Phatlamphu044 \\
\hline Loganiaceae & Strychnos nux-blanda & Tumka Khao & $\mathrm{Me}$ & 100 & $\begin{array}{l}\text { Bring hardwood lie by the fire as the traditional postpartum healing, boil } \\
\text { and mix with water and bath to wound healing and drink as Lactagogue. }\end{array}$ & 0.03 & Phatlamphu126 \\
\hline Lythraceae & Punica granatum & Mak pila & Fo, Me & $\begin{array}{l}33 \\
67\end{array}$ & $\begin{array}{l}\text { Boil leaf to cure diarrhea. } \\
\text { Boil root and drink to cough relief, used root as the crude drug ingredient } \\
\text { to cure influenza. }\end{array}$ & 0.38 & Phatlamphu007 \\
\hline Malvaceae & Bombax anceps & Ngio pa & $\mathrm{Me}$ & $\begin{array}{l}50 \\
50\end{array}$ & $\begin{array}{l}\text { Boil bark mix with water and drink as a blood tonic. } \\
\text { Boil bark mix with water and drink as a element tonic (roborant). }\end{array}$ & 0.05 & Phatlamphu124 \\
\hline Malvaceae & Helicteres isora & Po bit & $\mathrm{Me}$ & 100 & $\begin{array}{l}\text { Bring hardwood lie by the fire as the traditional postpartum healing, boil } \\
\text { and mix with water and bath to wound healing and drink as Lactagogue. }\end{array}$ & 0.05 & Phatlamphu125 \\
\hline Melastomataceae & Osbeckia stellata & En a khon & $\mathrm{Me}$ & 100 & $\begin{array}{l}\text { Pound root with water and masking to treat the venomous, drink as an } \\
\text { antidote. }\end{array}$ & 0.05 & Phatlamphu102 \\
\hline Meliaceae & Azadirachta indica & Sadao & Fo & - & Eaten as vegetable. & 1.00 & Phatlamphu068 \\
\hline Meliaceae & Dysoxylum parasiticum & Langsat & Fo & - & Eaten as fruit. & 0.10 & Phatlamphu065 \\
\hline Menispermaceae & Cissampelos pareira & Krung kha mao & $\mathrm{Me}$ & 100 & Rubbing root and bark mix with water and drink to as a blood tonic. & 0.10 & Phatlamphu127 \\
\hline Menispermaceae & Tiliacora triandra & Ya nang & Fo & - & Used leaf as food ingredient. & 1.00 & Phatlamphu033 \\
\hline Moraceae & Artocarpus heterophyllus & Khanun & $\begin{array}{l}\text { Fo, Dy, } \\
\mathrm{Cu}\end{array}$ & - & $\begin{array}{l}\text { Eaten as fruit, used resin as a dyer, local people grown Khanun (jack- } \\
\text { fruit) at the front of their house as they believe that Khanun would help } \\
\text { the inhabitant get support from other people in work life (local belief). }\end{array}$ & 1.35 & Phatlamphu063 \\
\hline Moraceae & Ficus sarmentosa & Ma kra thueb rong & $\mathrm{Me}$ & $\begin{array}{l}50 \\
50\end{array}$ & $\begin{array}{l}\text { Boil bark mix with water and drink as a blood tonic. } \\
\text { Boil bark mix with water and drink as a element tonic (roborant). }\end{array}$ & 0.03 & Phatlamphu101 \\
\hline Moraceae & Morus alba & Mon & Fo & - & Eaten as fruit. & 0.10 & Phatlamphu113 \\
\hline Moraceae & Streblus asper & Khoi & $\mathrm{Me}$ & 100 & Used wood as a dental care. & 0.05 & Phatlamphu109 \\
\hline Muntingiaceae & Muntingia calabura & Mak khop & Fo & - & Eaten as fruit. & 1.00 & Phatlamphu066 \\
\hline Musaceae & Musa $\times$ paradisiaca & Kluai namwa & $\begin{array}{l}\text { Fo, } \mathrm{Me}, \\
\mathrm{Dy}, \mathrm{Cu}\end{array}$ & 100 & $\begin{array}{l}\text { Eaten as fruit, used as crude drug flavoring, used resin as a dyer, used } \\
\text { their fruit and aerial part in the auspicious ceremony. }\end{array}$ & 1.50 & Phatlamphu008 \\
\hline Myrtaceae & Psidium guajava & Mak see da & Fo & - & Eaten as fruit. & 1.00 & Phatlamphu009 \\
\hline Myrtaceae & Syzygium antisepticum & Phak mek & Fo & - & Eaten as vegetable. & 1.00 & Phatlamphu035 \\
\hline Myrtaceae & Syzygium cumini & Wa & Fo & - & Eaten as fruit. & 0.58 & Phatlamphu010 \\
\hline Nelumbonaceae & Nelumbo nucifera & Bua luang & Fo & - & Eaten as fruit. & 0.70 & Phatlamphu011 \\
\hline Nelumbonaceae & Nymphaea pubescens & Bua sai & Fo & - & Eaten as vegetable. & 0.70 & Phatlamphu013 \\
\hline Opiliaceae & Melientha suavis & Phak wan & Fo & - & Eaten as vegetable. & 0.88 & Phatlamphu014 \\
\hline
\end{tabular}




\begin{tabular}{|c|c|c|c|c|c|c|c|}
\hline Oxalidaceae & Averrhoa carambola & Mak fueang & Fo & - & Eaten as fruit. & 0.58 & Phatlamphu012 \\
\hline Phyllanthaceae & Bauhinia saccocalyx & Siao & $\mathrm{Me}$ & 100 & Boil root and drink as the traditional postpartum healing. & 0.03 & Phatlamphu082 \\
\hline Phyllanthaceae & Phyllanthus reticulatus & Kang pla khruea & $\mathrm{Me}$ & 100 & Pound root and mix with water and drink as antidote. & 0.05 & Phatlamphu087 \\
\hline Phyllanthaceae & Sauropus androgynus & Phak wan ban & Fo & - & Eaten as vegetable. & 0.08 & Phatlamphu045 \\
\hline Piperaceae & Piper nigrum & Phrik thai & Fo & - & Eaten as vegetable, used as food ingredient. & 1.00 & Phatlamphu041 \\
\hline Piperaceae & Piper sarmentosum & Cha phlu & Fo & - & Eaten as vegetable, used as food ingredient. & 1.00 & Phatlamphu042 \\
\hline Plantaginaceae & Limnophila aromatica & Phak kha yaeng & Fo & - & Eaten as vegetable, used as food ingredient. & 1.00 & Phatlamphu056 \\
\hline Poaceae & Bambusa bambos & Phai pa & Fo, Eq & - & $\begin{array}{l}\text { Boil and eaten as vegetable, used as food ingredient, used stem as a } \\
\text { equipment in daily life. }\end{array}$ & 2.00 & Phatlamphu060 \\
\hline Poaceae & Cymbopogon citratus & Ta khrai & Fo, Me & $\begin{array}{l}25 \\
75\end{array}$ & $\begin{array}{l}\text { Used as compress ball ingredient to pain relief in Thai Massage. } \\
\text { Bring whole plant lie by the fire as the traditional postpartum healing. }\end{array}$ & 1.00 & Phatlamphu034 \\
\hline Poaceae & Oryza sativa & Khao & Fo, Me & 100 & Eaten as main foods, used as the crude drug to cure kidney disease. & 1.00 & Phatlamphu 140 \\
\hline Poaceae & Saccharum $x$ sinense & Oi dam & Fo, Me & 100 & Used as crude drug flavoring. & 0.30 & Phatlamphu100 \\
\hline Polygonaceae & Persicaria odorata & Phak phaeo & Fo & - & Eaten as vegetable. & 1.00 & Phatlamphu040 \\
\hline Rhamnaceae & Berchemia floribunda & Ho sa phai khwai & $\mathrm{Me}$ & $\begin{array}{l}50 \\
50\end{array}$ & $\begin{array}{l}\text { Boil hardwood mix with water and drink as a blood tonic. } \\
\text { Boil hardwood mix with water and drink as a element tonic (roborant). }\end{array}$ & 0.05 & Phatlamphu108 \\
\hline Rhamnaceae & Ziziphus attopensis & Kamlang suea khrong & $\mathrm{Me}$ & $\begin{array}{l}50 \\
50\end{array}$ & $\begin{array}{l}\text { Boil hardwood mix with water and drink as a blood tonic. } \\
\text { Boil hardwood mix with water and drink as a element tonic (roborant). }\end{array}$ & 0.23 & Phatlamphu027 \\
\hline Rhamnaceae & Ziziphus oenopolia & Lep yiao & Fo, Me & 100 & Eaten as fruit or as a laxative. & 0.35 & Phatlamphu069 \\
\hline Rubiaceae & Ixora finlaysoniana & Khem & $\mathrm{Me}$ & 100 & Used as crude drug ingredient to cure hemorrhoid. & 0.05 & Phatlamphu112 \\
\hline Rubiaceae & Morinda citrifolia & Yo & $\mathrm{Fo}, \mathrm{Cu}$ & - & $\begin{array}{l}\text { Used as food ingredient, local people grown Yo at the front of their } \\
\text { house as they believe that Yo would help the inhabitant get praise from } \\
\text { other people (local belief). }\end{array}$ & 0.83 & Phatlamphu090 \\
\hline Rutaceae & Citrus hystrix & Bak krut & $\begin{array}{l}\text { Fo, Me, } \\
\text { De }\end{array}$ & 100 & $\begin{array}{l}\text { Used leaf as food ingredient, cut fruit into pieces and mix with other } \\
\text { crude drug ingredients as compress ball ingredient to pain relief in Thai } \\
\text { Massage. }\end{array}$ & 1.90 & Phatlamphu062 \\
\hline Rutaceae & Citrus $x$ aurantiifolia & Bak nao & Fo, Me & 100 & $\begin{array}{l}\text { Used fruit as food ingredient, used fruit as the crude drug to cure kidney } \\
\text { disease. }\end{array}$ & 1.03 & Phatlamphu061 \\
\hline Rutaceae & Clausena wallichii & Song fa & $\mathrm{Me}$ & 100 & Boil root and drink to cough relief. & 0.08 & Phatlamphu081 \\
\hline Sapindaceae & Dimocarpus longan & Lamyai & Fo & - & Eaten as fruit. & 1.00 & Phatlamphu064 \\
\hline Sapotaceae & Xantolis cambodiana & Tan nom & $\mathrm{Me}$ & 100 & Boil hardwood and drink as a galactagogue. & 0.08 & Phatlamphu107 \\
\hline Simaroubaceae & Eurycoma longifolia & Pla lai phueak & $\mathrm{Me}$ & 100 & Boil stem and drink and mix with water to bath to cure abscess. & 0.08 & Phatlamphu086 \\
\hline Smilacaceae & Smilax corbularia & Khao yen nuea & $\mathrm{Me}$ & $\begin{array}{l}20 \\
20 \\
20 \\
40\end{array}$ & $\begin{array}{l}\text { Boil fruit mix with water and drink as a blood tonic. } \\
\text { Boil fruit mix with water and drink as a element tonic (roborant). } \\
\text { Used as a crud drug ingredient as a Leukemia treament. } \\
\text { Boil and drink to cure headache. }\end{array}$ & 0.10 & Phatlamphu083 \\
\hline Smilacaceae & Smilax glabra & Khao yen tai & $\mathrm{Me}$ & $\begin{array}{l}20 \\
20 \\
20 \\
40\end{array}$ & $\begin{array}{l}\text { Boil fruit mix with water and drink as a blood tonic. } \\
\text { Boil fruit mix with water and drink as a element tonic (roborant). } \\
\text { Used as a crud drug ingredient as a Leukemia treament. } \\
\text { Boil and drink to cure headache. }\end{array}$ & 0.10 & Phatlamphu084 \\
\hline Solanaceae & Capsicum аппиит & Phrik & Fo & - & Used as food ingredient. & 1.00 & Phatlamphu051 \\
\hline Solanaceae & Solanum heterodoxum & Ma khuea & Fo & - & Eaten as vegetable, used as food ingredient. & 1.00 & Phatlamphu036 \\
\hline Solanaceae & Solanum lasiocarpum & MakUaek & Fo & - & Used as food ingredient. & 0.08 & Phatlamphu037 \\
\hline Solanaceae & Solanum lycopersicum & Maklen & Fo & - & Eaten as vegetable, used as food ingredient. & 1.00 & Phatlamphu038 \\
\hline
\end{tabular}




\begin{tabular}{|c|c|c|c|c|c|c|c|}
\hline Solanaceae & Solanum stramoniifolium & Mak khaeng & Fo, $\mathrm{Me}$ & 50 & $\begin{array}{l}\text { Bring hardwood lie by the fire as the traditional postpartum healing } \\
\text { (medicine). } \\
\text { Used fruit as food ingredient, cut fruit into pieces and mix with other } \\
\text { crude drug ingredients as compress ball ingredient to pain relief in Thai } \\
\text { Massage (medicine). } \\
\text { Eaten as vegetable, used as food ingredient (food). }\end{array}$ & 1.05 & Phatlamphu055 \\
\hline Sterculiaceae & Mansonia gagei & Chan Hom & $\mathrm{Me}$ & 100 & Used root as crude drug ingredient to cure influenza. & 0.08 & Phatlamphu085 \\
\hline Zingiberaceae & Alpinia galanga & Kha & Fo & - & Used as food ingredient. & 1.00 & Phatlamphu039 \\
\hline Zingiberaceae & Boesenbergia rotunda & Krachai & Fo & - & Used as food ingredient. & 1.00 & Phatlamphu070 \\
\hline Zingiberaceae & Curcuma comosa & Wan chak motluk & $\mathrm{Me}$ & $\begin{array}{l}33 \\
67\end{array}$ & $\begin{array}{l}\text { Used root as crude drug ingredient to pain relief. } \\
\text { Bring rhizome lie by the fire as the traditional postpartum healing. }\end{array}$ & 0.08 & Phatlamphu088 \\
\hline Zingiberaceae & Curcuma longa & Khamin & Fo, $\mathrm{Me}$ & 25 & $\begin{array}{l}\text { Used rhizome as crude drug ingredients as compress ball ingredient to } \\
\text { pain relief in Thai Massage. } \\
\text { Bring rhizome lie by the fire as the traditional postpartum healing. }\end{array}$ & 0.33 & Phatlamphu003 \\
\hline Zingiberaceae & Curcuma sessilis & Krachiao & Fo & - & Eaten as vegetable. & 0.05 & Phatlamphu001 \\
\hline Zingiberaceae & Kaempferia galanga & Pro hom & Fo & - & Eaten as vegetable. & 0.05 & Phatlamphu002 \\
\hline Zingiberaceae & Zingiber montanum & Wan fai & $\mathrm{Me}$ & 25 & $\begin{array}{l}\text { Used rhizome as crude drug ingredients as compress ball ingredient to } \\
\text { pain relief in Thai Massage. }\end{array}$ & 0.08 & Phatlamphu089 \\
\hline & & & & 75 & Bring rhizome lie by the fire as the traditional postpartum healing. & & \\
\hline
\end{tabular}

Note: ${ }^{*}$ Use categories: Fo: Food, Me: Medicine, Dy: Dyer, Co: Cosmetic, Eq: Equipment, Cu: Culture, Deodorize: De 
Table 3. Informant consensus factor (ICF) of used-categories

\begin{tabular}{|c|c|c|c|c|}
\hline Used-categories & Treated ailments & $\begin{array}{l}\text { Number of } \\
\text { use-report }\end{array}$ & $\begin{array}{c}\text { Number of } \\
\text { species }\end{array}$ & ICF \\
\hline Injuries & Wound, pains & 4 & 2 & 1.00 \\
\hline Headache & Pain & 4 & 2 & 0.67 \\
\hline Neutralize, antidote & Venomous insect bite & 6 & 3 & 0.60 \\
\hline Pregnancy/Birth/Puerperium & Rejuvenate after giving child & 35 & 16 & 0.56 \\
\hline Skin disorders & Wound, Pain, irritated relief & 6 & 4 & 0.33 \\
\hline Muscle and skeleton disorders & Muscle pain relief & 13 & 10 & 0.25 \\
\hline Respiration system & Cough, fever, influenza & 12 & 10 & 0.18 \\
\hline Digestion system & Diarrhea, Flatulence, stomach ache & 17 & 15 & 0.13 \\
\hline Endocrine system & Diabetes & 1 & 1 & 0.00 \\
\hline Urinary system & Dysuria & 2 & 2 & 0.00 \\
\hline Malignant tumor, Cancer & Supportive treatment & 3 & 3 & 0.00 \\
\hline Blood tonic & - & 6 & 6 & 0.00 \\
\hline Element tonic, body strength & Body nourishment & 7 & 7 & 0.00 \\
\hline Infection & Abscess, Hemorrhoids & 6 & 6 & 0.00 \\
\hline Other & Crude drug flavouring & 2 & 2 & 0.00 \\
\hline
\end{tabular}

Table 4. Jaccard's Similarity Index for pairs of communities in the sample of edible plants used in Muang District, Kalasin Province, Thailand

\begin{tabular}{|c|c|c|c|c|}
\hline & Urban \&semi-urban & Wetland community & Forest community & Community in valley \\
\hline Urban \& Semi-urban & - & 0.2829 & 0.2640 & 0.2863 \\
\hline Wetland community & - & - & 0.2971 & 0.2877 \\
\hline Community in valley & - & - & - & - \\
\hline
\end{tabular}

\section{Jaccard's Similarity Index (JI)}

This comparative study classified 17 sub-districts in Muang District, Kalasin Province with their dominant spatial features based on land location or land use pattern into four communities. The JI values were low to average, and varied between 0.2640 and 0.2971 (Table 4). UPGMA cluster analysis showed that the communities with the closest number of edible plant species used were in the same groups, such as WC FC and CV. The cluster diagram separated UB from the other communities to an isolated position, which is apparent from the different land uses (Figure 5). The highest JI was for the pair of WC and FC (0.2971). This shows that these two communities were the most similar community pair as WC and FC were the only two communities that had folk healers who had traditional knowledge about edible plant usage to cure diseases, and they had similar practices for the preparation processes or the same folk medical remedies. This is the reason that these communities have the highest number of edible plant species in both communities (113 and 107 species, respectively). The lowest JI was for the pair of UB and FC $(0.2640)$ when the number of edible plant species used in the capital of the province and the adjacent area is low (71 species), and the people in UB do not use the edible plants for several purposes. For example, Muang and Loup, which are neighboring sub-districts to the capital of the province, both sub-districts are the location of important places in Kalasin Province, such as the government complex, academic institute, factories and economic zones (municipal market, convenience and department store, restaurants, etc.). This is similarly, to a comparative study using JI values and UPGMA cluster analysis that provided numerical and graphic illustrations of medicinal plant species used in 17 Karen villages in northern Thailand (Tangjitman et al. 2013). Moreover, the edible plants that are used for traditional treatments can be grown in home gardens as important habitats and also in nature conservation, and this is an important factor that ensures rural communities have more edible species in their area (Barbhuiya et al. 2015; Panyadee et al. 2019). However, there is the possibility that the similarity of edible plant uses in Muang District, Kalasin Province are not dependent on the different land uses only, and that communities with a folk healer tend to have a higher number of edible plant uses than the communities without a person with traditional knowledge (Mollik et al. 2010; Biswas et al. 2011). Therefore, it can be concluded that traditional healers are important for plant diversity based on their benefits. 


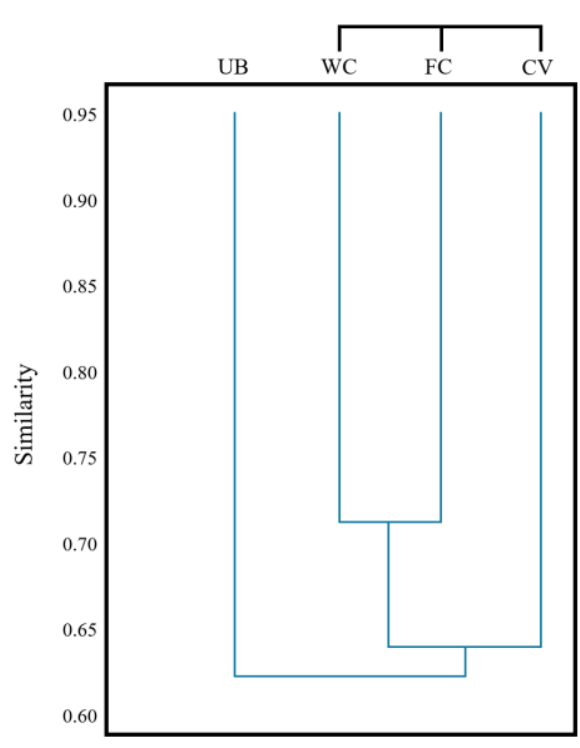

Figure 5. UPGMA cluster analysis of edible plant species used in Muang District, Kalasin Province, Thailand based on Jaccard's Similarity Index. Communities grouped in same square bracket indicate greater similarities between those communities. UB: Urban and semi-urban; WC: wetland community; FC: forest community; and $\mathrm{CV}$ : community in valley

The result of this ethnobotanical study shows that the edible plants used in Muang District, Kalasin Province tend to be at risk of traditional botanical knowledge loss due to the expansion of urban areas and the accessibility to modern medicine, and this might have an effect on the diversity of edible plant species that are used as medicine. However, WC, FC and CV represent communities in which people still keep strong knowledge about edible plants that can be used as food and grown in nature and home gardens. This indicates that the indigenous people in Muang District, Kalasin Province have automatically transferred their knowledge of their food culture to their descendants, while knowledge of traditional medicine has not been shared from the old generation to the younger people widely. Therefore, we should be concerned that there is a great amount of knowledge that will forever be lost in the near future; recognition should be given to traditional medicine knowledge and natural resources management by education and providing information or the training programs by the agencies involved. Beyond that, the edible plants could have their appearance transformed to be valuable products for further study. This would help people to secure their income and other benefits that can be obtained from the edible plants.

\section{ACKNOWLEDGEMENTS}

We fully acknowledge the key informants of Muang District, Kalasin Province, Thailand for sharing their local knowledge on the use of plants. This study was financially supported by Mahasarakham University, Thailand. We are extremely grateful to Walai Rukhavej Botanical Research Institute, Mahasarakham University for allowing us to use their facilities during the field work. Without their contribution, this study would have been impossible, thanks to Dr. Jolyon Dodgson for language editing and suggestions to improve the manuscript.

\section{REFERENCES}

Barbhuiya AR, Sahoo UK, Upadhyaya K. 2016. Plant Diversity in the Indigenous Home Gardens in the Eastern Himalayan Region of Mizoram, Northeast India. Econ Bot 70 (2): 115-131. DOI: 10.1007/s12231-016-9349-8.

Bhatia H, Sharma YP, Manhas RK, Kumar K. 2018. Traditionally used wild edible plants of district Udhampur, J\&K, India. J Ethnobiol Ethnomed 14 (1): 1-13. DOI: 10.1186/s13002-018-0272-1.

Biswas A, Haq WM, Akber M, Ferdausi D, Seraj S, Jahan F, Chowdhury AR, Rahmatullah M. 2011. Survey of medicinal plants used by folk medicinal practitioners of Paschim Shawra and Palordi Villages of Gaurnadi Upazila in Barisal District, Bangladesh. Am-Eurasian J Sustain Agric 5 (1): 15-22.

Choenkwan S, Fox JM, Rambo AT. 2014. Agriculture in the mountains of Northeastern Thailand: Current situation and prospects for development. Mt Res Dev 34 (2): 95-106. DOI: 10.1659/MRDJOURNAL-D-13-00121.1.

Christenhusz MJM, Byng JW. 2016. The number of known plants species in the world and its annual increase. Phytotaxa 261 (3): 201-217. DOI: 10.11646/phytotaxa.261.3.1.

Cramb R. 2020. White gold: The commercialisation of rice farming in the lower Mekong Basin. Palgrave Macmillan, London. DOI: 10.1007/978-981-15-0998-8.

Cruz-Garcia GS, Struik PC, Johnson DE. 2016. Wild harvest: distribution and diversity of wild food plants in rice ecosystems of Northeast Thailand. NJAS - Wageningen J Life Sci 78: 1-11. DOI: 10.1016/j.njas.2015.12.003.

Fernando WGD. 2012. Plants: An international scientific open access journal to publish all facets of plants, their functions and interactions with the environment and other living organisms. Plants 1 (1): 1-5. DOI: 10.3390/plants1010001.

Grünbühel CM, Haberl H, Schandl H, Winiwarter V. 2003. Socioeconomic metabolism and colonization of natural processes in sangsaeng village: Material and energy flows, land use, and cultural change in Northeast Thailand. Hum Ecol 31 (1): 53- 86. DOI: 10.1023/A:1022882107419.

Gwalwanshi DR, Vyas D, Bishwas AJ, Salunkhe O, Tiwari P. 2014. Ethnomedicinal and ecological studies on Fabaceae of Runj Forest Panna (Mp), India. Intl J Recent Sci Res 5 (7): 1264-1269.

Hammer $\varnothing$, Harper DAT, Ryan PD. 2001. PAST: Paleontological Statistics Software Package for Education and Data Analysis. Palaeontologia Electronica 4: 1-9.

Inta A, Trisonthi P, Trisonthi C. 2013. Analysis of traditional knowledge in medicinal plants used by Yuan in Thailand. J Ethnopharmacol 149 (2013): 344-354. DOI: 10.1016/j.jep.2013.06.047.

Jaccard P. 1902. Lois de destributionflorale dans la zone alpine. Bulletin Société Vaudoise des Sciences Naturelles 38: 69-130.

Junsongduang A, Balslev H, Inta A, Jampeetong A, Wangpakapattanawong P. 2013. Medicinal plants from swidden fallows and sacred forest of the Karen and the Lawa in Thailand. J Ethnobiol Ethnomed 9 (1): 1-10. DOI: 10.1186/1746-4269-9-44.

Kalasin provincial office SIPD. 2019. General Information on Kalasin. Strategy and Information for Provincial Development Unit (SIPD). Provincial Governor's Office. Kalasin.http://www.kalasin.go.th.

Katiyar C, Kanjilal S, Gupta A, Katiyar S. 2012. Drug discovery from plant sources: An integrated approach. AYU (Intl Q J Res Ayurveda) 33 (1): 10-19. DOI: 10.4103/0974-8520.100295.

Kayani S, Ahmad M, Sultana S, Shinwari ZK, Zafar M, Yaseen G, Hussain M, Bibi T. 2015. Ethnobotany of medicinal plants among the communities of Alpine and Sub-alpine regions of Pakistan. J Ethnopharmacol 164: 186-202. DOI: 10.1016/j.jep.2015.02.004.

Kew Science. 2021. World Checklist of Selected Plant Families (WCSP).

Khuankaew S, Srithi K, Tiansawat P, Jampeetong A, Inta A, Wangpakapattanawong P. 2014. Ethnobotanical study of medicinal 
plants used by Tai Yai in Northern Thailand. J Ethnopharmacol 151 (2): 829-838. DOI: 10.1016/j.jep.2013.11.033.

Khuntayaporn P, Suksiriworapong J. 2017. Efficacy of essential oil formulations against malodor causing bacteria. Pharm Sci Asia 44 (4): 209-216. DOI: 10.29090/psa.2017.04.209.

Liana A, Purnomo P, Sumardi I, Daryono BS 2017. Ethnobotany of Bamboo in Sangirese, North Celebes. Biosaintifika: Intl J Biol Educ 9 (1): 81. DOI: 10.15294/biosaintifika.v9i1.7405.

Menendez-Baceta G, Aceituno-Mata L, Tardío J, Reyes-García V, Pardode-Santayana M. 2012. Wild edible plants traditionally gathered in Gorbeialdea (Biscay, Basque Country). Genet Resour Crop Evol 59 (7): 1329-1347. DOI: 10.1007/s10722-011-9760-z.

Molares S, Ladio A. 2012. The usefulness of edible and medicinal Fabaceae in Argentine and Chilean Patagonia: Environmental availability and other sources of supply. Evidence-Based Complement Altern Med 2012. DOI: 10.1155/2012/901918.

Mollik MAH, Hossan MS, Paul AK, Taufiq-Ur-Rahman M, Jahan R, Rahmatullah M. 2010. A comparative analysis of medicinal plants used by folk medicinal healers in three districts of Bangladesh and Inquiry as to mode of selection of medicinal plants. Ethnobot Res Appl 8: 195-218. DOI: 10.17348/era.8.0.195-218.

Mustafa B, Hajdari A, Krasniqi F, Hoxha E, Ademi H, Quave CL, Pieroni A. 2012. Medical ethnobotany of the Albanian Alps in Kosovo. J Ethnobiol Ethnomed 8: 1-14. DOI: 10.1186/1746-4269-8-6.

Noomhorm N, Chun-Ju C, Che-Sheng W, Jir-You W, Jiun-Liang C, LingMing T, Wei-Shone C, Jen-Hwey C, Yi-Ming S. 2014. In vitro and in vivo effects of Xanthorrhizol on human breast cancer MCF-7 cells treated with Tamoxifen. J Pharmacol Sci 125 (4): 375-385. DOI: 10.1254/jphs.14024FP.

Numpulsuksant W, Saensouk S, Saensouk, P. 2021. Diversity and ethnobotanical study of medicinal plants in Ban Hua Kua, Kae Dam District, Thailand. Biodiversitas 22 (10): 4349-4357. DOI: $10.13057 /$ biodiv/d221027.

Oladeji OS, Adelowo FE, Oluyori AP. 2021. The genus Senna (Fabaceae): A review on its traditional uses, botany, phytochemistry, pharmacology and toxicology. South Afr J Bot 138: 1-32. DOI: 10.1016/j.sajb.2020.11.017.

Ong HG, Kim YD. 2017. The role of wild edible plants in household food security among transitioning hunter-gatherers: evidence from the Philippines. Food Secur 9: 11-24. DOI: 10.1007/s12571-016-0630-6.

Panyadee P, Balslev H, Wangpakapattanawong P, Inta A. 2019. Medicinal plants in homegardens of four ethnic groups in Thailand. J Ethnopharmacol 239: 111927. DOI: 10.1016/j.jep.2019.111927.

Pholhiamhan R, Saensouk S, Saensouk P. 2018. Ethnobotany of Phu Thai ethnic group in Nakhon Phanom province, Thailand. Walailak J Sci Technol 15 (10): 679-699. DOI: 10.48048/wjst.2018.3737.

Punchay K, Inta A, Tiansawat P, Balslev H, Wangpakapattanawong P. 2020. Traditional knowledge of wild food plants of Thai Karen and Lawa (Thailand). Genet Resour Crop Evol 67 (5): 1277-1299. DOI: 10.1007/s10722-020-00910-x.

Rahman AHMM, Parvin MIA. 2014. Study of Medicinal Uses on Fabaceae Family at Rajshahi, Bangladesh. Res Plant Sci 2 (1): 6-8. DOI: 10.12691/plant-2-1-2.

Ramli MR, Milow P, Malek S. 2021. Diversity and traditional knowledge of medicinal plants in home gardens of Kampung Masjid Ijok, Perak, Malaysia. Biodiversitas 22 (5): 2458-2465. DOI: 10.13057/biodiv/d220502.

Reyes-García V, Guèze M, Luz AC, Paneque-Gálvez J, Macía MJ, OrtaMartínez M, Pino J, Rubio-Campillo X. 2013. Evidence of traditional knowledge loss among a contemporary indigenous society. Evol Hum Behav 34 (4): 249-257. DOI: 10.1016/j.evolhumbehav.2013.03.002.
Robinson DF. 2007. Biodiversity-Related Traditional Knowledge in Thailand: Intellectual Property Relations and Geographies of Knowledge Regulation.

Saensouk P, Saensouk S. 2021. Diversity, traditional use and conservation status of Zingiberaceae in Udorn Thani Province, Thailand. Biodiversitas 22 (8): 3083-3097. DOI: 10.13057/biodiv/d220801.

Saensouk S, Saensouk P, Pasorn P, Chantaranothai P. 2016. Diversity, traditional uses and new record of Zingiberaceae in Nam Nao National Park, Petchabun Province, Thailand. Agric Nat Resour 50: 445-453. DOI: 10.1016/j.anres.2016.08.002.

Saisor N, Prathepha P, Saensouk S. 2021. Ethnobotanical study and utilization of plants in Khok Nhong Phok forest, Kosum Phisai District, Northeastern Thailand. Biodiversitas 22 (10): 4336-4348. DOI: $10.13057 /$ biodiv/d221026.

Silalahi M, Nisyawati. 2018. The ethnobotanical study of edible and medicinal plants in the home garden of Batak Karo sub-ethnic in North Sumatra, Indonesia. Biodiversitas 19 (1): 229-238. DOI: 10.13057/biodiv/d190131.

Srithi K, Balslev H, Wangpakapattanawong P, Srisanga P, Trisonthi C. 2009. Medicinal plant knowledge and its erosion among the Mien (Yao) in northern Thailand. J Ethnopharmacol 123 (2): 335-342. DOI: 10.1016/j.jep.2009.02.035.

Supiandi MI, Mahanal S, Zubaidah S, Julung H, Ege B. 2019. Ethnobotany of traditional medicinal plants used by Dayak Desa community in Sintang, West Kalimantan, Indonesia. Biodiversitas 20 (5): 1264-1270. DOI: 10.13057/biodiv/d200516.

Susandarini R, Khasanah U, Rosalia N. 2021. Ethnobotanical study of plants used as food and for maternal health care by the Malays communities in Kampar Kiri Hulu, Riau, Indonesia. Biodiversitas 22 (6): 3111-3120. DOI: 10.13057/biodiv/d220613.

Sutjaritjai N, Wangpakapattanawong P, Balslev H, Inta A. 2019. Traditional uses of Leguminosae among the Karen in Thailand. Plants 8 (12). DOI: 10.3390/plants8120600.

Tangjitman K, Wongsawad C, Winijchaiyanan P, Sukkho T, Kamwong K, Pongamornkul W, Trisonthi C. 2013. Traditional knowledge on medicinal plant of the Karen in northern Thailand: A comparative $\begin{array}{llll}\text { study. J Ethnopharmacol } 150 \text { (1): 232-243. DOI: } & \end{array}$ 10.1016/j.jep.2013.08.037.

Tardío J, Pardo-de-Santayana M. 2008. Cultural importance indices: A comparative analysis based on the useful wild plants of Southern Cantabria (Northern Spain). Econ Bot 62 (1): 24-39. DOI: 10.1007/s12231-007-9004-5.

Thongpukdee A, Thepsithar C, Thammaso C. 2014. Ethnobotanical survey of vegetable plants traditionally used in Kalasin Thailand. Intl J Biol Biomol Agric Foods Biotechnol Eng 8 (7): 692-695.

Trotter RT, Logan MH. 2019. Informants consensus: A new approach for identifying potentially effective medicinal plants. In: Etkin NL (ed) Plants in Indigenous Medicine and Diet. Redgrave Publishing, New York, Bedford Hill. DOI: 10.4324/9781315060385-6.

Vongthip W, Sillapachaiyaporn C, Kyu-Won K, Sukprasansap M, Tencomnao T. 2021. Thunbergia laurifolia leaf extract inhibits glutamate-induced neurotoxicity and celldeath through mitophagy signaling. Antioxidants 10 (11): 1678. DOI: 10.3390/antiox10111678.

United Nations CERD. 2011. Number of ethnic group population in the northeast (Esan) by language family group. Reports submitted by States parties under article 9 of the Convention. International Convention on the Elimination of All Forms of Racial Discrimination. United Nations, Bangkok.

Wongpanit B, Chotikamas S, Roddecha S, Tantayotai P, Sriariyanun M. 2018. Study of mathematical models in hot air drying of herbs in herbal compress ball. MATEC Web Conf 187: 1-5. DOI: 10.1051/matecconf/201818701002. 